\title{
Tylosin Levels in the Tissue of Pig after Medication in Drinking Water
}

\author{
Yoshikazu IrItani, Shigetada Hidaka, Tetsuo Kitabatake* \\ and Teruaki ISE* \\ Aburahi Laboratories, Shionogi \& Co., Ltd., Shiga-ken 520-34 \\ *Animal Health Products, Shionogi \& Co., Ltd., Osaka-shi 541
}

(Received March 12, 1975)

Tylosin is a macroride antibiotic, exhibiting activity in vitro against most gram-positive organisms and certain gram-negative organisms. ${ }^{1}$. It has been widely used for domestic animals and fowls as a feed additive in the drinking water or so. In swine, several investigators reported that tylosin was highly effective against swine dysentery in the field. $2,3,4,5)$ However, HuBER stated a large residue of certain antibiotics is harmful for human health. ${ }^{6}$.

The present study is undertaken to determine the residual tylosin in the tissues of the pig treated with tylosin tartrate in the drinking water.

\section{Materials and Methods}

Ninety-day-old pigs which had been given a feed free from antibiotics for 2 weeks until the start of the experiments were used. A total of 30 pigs was divided into 3 groups. Two groups were medicated with $0.025 \%$ (Group A) or $0.05 \%$ (Group B) of tylosin tartrate in drinking water for 5 days. The Group $C$ was not medicated. The pigs of each group were sacrificed at $0,1,2$ and 5 days after treatment. Tissue samples were frozen until being ex-

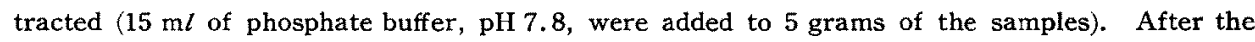
sample was homogenized, the suspension was kept at $4^{\circ} \mathrm{C}$ for 18 to 24 hours, and then, was centrifuged at $2500 \mathrm{rpm}$ for 10 minutes. Amounts of residual tylosin in supernatant were assayed by the cylinder cup method, using a strain of SARCINIA LUTEA (ATCC 9341).

\section{Results and Discussion}

Senstivity of standard tylosin obtained in this experiment ranged from 0.06 to $0.18 \mathrm{ppm}$ with an average of $0.15 \mathrm{ppm}$. These values of sensitivity coincide closely with the value reported by other investigators. ${ }^{7,8)}$

After treatment in the drinking water for 5 days, a total amount of tylosin per pig was given $121.6 \mathrm{mg} / \mathrm{kg}$ in group $\mathrm{A}$ and $243.7 \mathrm{mg} / \mathrm{kg}$ in group $\mathrm{B}$ on the average. Tylosin residues in the tissue of pigs are shown in Table 1. In group A, tylosin could not be detected in muscle, heart, kidney, liver, stomach, duodenum and marrow at 0 to 5 days after treatment. Only in group B, a small amount of residue of tylosin was found in the bone marrow (No. 12) and duodenum (No. 16). 
Tylosin Residues in Tissue of Pigs

Table 1. Rusuide of tylosin in the tissue of pigs treated with the drinking water for 5 days

\begin{tabular}{|c|c|c|c|c|c|c|c|c|c|c|c|c|}
\hline \multirow{2}{*}{ 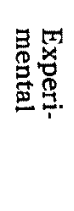 } & \multirow{2}{*}{ 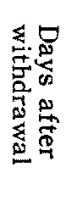 } & \multirow{2}{*}{$\begin{array}{l}\frac{\pi}{0} \\
z \\
0 \\
0\end{array}$} & \multicolumn{10}{|c|}{ Tylosin levels in tested organ (ppm) } \\
\hline & & & 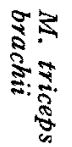 & 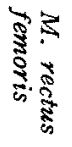 & 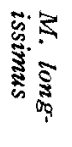 & $\begin{array}{l}\text { T/ } \\
\stackrel{9}{7} \\
\frac{1}{7}\end{array}$ & $\begin{array}{l}\frac{0}{0} \\
\frac{0}{8}\end{array}$ & 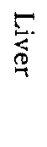 & 容 & 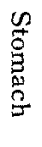 & 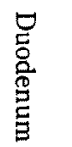 & $\begin{array}{l}3 \\
\frac{3}{3} \\
\frac{7}{\xi}\end{array}$ \\
\hline \multirow{9}{*}{ A } & & 1 & o & 0 & 0 & 0 & 0 & 0 & 0 & 0 & 0 & 0 \\
\hline & 0 & 2 & 0 & 0 & 0 & 0 & 0 & 0 & 0 & 0 & 0 & 0 \\
\hline & & 3 & 0 & 0 & 0 & 0 & 0 & 0 & 0 & 0 & 0 & 0 \\
\hline & & 4 & 0 & 0 & 0 & 0 & 0 & 0 & 0 & 0 & 0 & 0 \\
\hline & 1 & 5 & 0 & 0 & 0 & 0 & 0 & 0 & 0 & 0 & 0 & 0 \\
\hline & & 6 & 0 & 0 & 0 & 0 & 0 & o & 0 & 0 & 0 & 0 \\
\hline & 2 & $\begin{array}{l}7 \\
8\end{array}$ & $\begin{array}{l}0 \\
0\end{array}$ & $\begin{array}{l}0 \\
0\end{array}$ & $\begin{array}{l}0 \\
0\end{array}$ & $\begin{array}{l}0 \\
0\end{array}$ & $\begin{array}{l}0 \\
0\end{array}$ & $\begin{array}{l}0 \\
0\end{array}$ & $\begin{array}{l}0 \\
0\end{array}$ & $\begin{array}{l}0 \\
0\end{array}$ & $\begin{array}{l}0 \\
0\end{array}$ & $\begin{array}{l}0 \\
0\end{array}$ \\
\hline & & 9 & 0 & 0 & 0 & 0 & 0 & 0 & 0 & 0 & 0 & 0 \\
\hline & 5 & 10 & 0 & 0 & 0 & 0 & 0 & 0 & 0 & 0 & 0 & 0 \\
\hline \multirow{10}{*}{ B } & & 11 & 0 & 0 & 0 & 0 & 0 & 0 & 0 & 0 & 0 & 0 \\
\hline & 0 & 12 & 0 & 0 & 0 & 0 & 0 & 0 & 0 & 0 & 0 & 0.6 \\
\hline & & I3 & 0 & 0 & 0 & 0 & 0 & 0 & 0 & 0 & 0 & 0 \\
\hline & & 14 & 0 & 0 & 0 & 0 & 0 & 0 & 0 & 0 & 0 & 0 \\
\hline & 1 & 15 & 0 & 0 & 0 & 0 & 0 & 0 & 0 & 0 & & 0 \\
\hline & & 16 & 0 & 0 & 0 & 0 & 0 & 0 & 0 & 0 & 0.42 & 0 \\
\hline & 2 & 17 & 0 & 0 & 0 & 0 & 0 & 0 & 0 & 0 & 0 & 0 \\
\hline & 2 & 18 & 0 & 0 & 0 & 0 & 0 & 0 & 0 & 0 & 0 & 0 \\
\hline & 5 & 19 & 0 & 0 & 0 & 0 & 0 & 0 & 0 & 0 & 0 & 0 \\
\hline & 3 & 20 & 0 & 0 & 0 & 0 & 0 & 0 & 0 & 0 & 0 & 0 \\
\hline \multirow{10}{*}{$C$} & & 21 & 0 & 0 & 0 & 0 & 0 & 0 & 0 & 0 & 0 & 0 \\
\hline & 0 & 22 & 0 & 0 & 0 & 0 & 0 & 0 & 0 & 0 & 0 & 0 \\
\hline & & 23 & 0 & 0 & 0 & 0 & 0 & 0 & 0 & 0 & 0 & 0 \\
\hline & & 24 & 0 & 0 & 0 & 0 & 0 & 0 & 0 & 0 & 0 & 0 \\
\hline & 1 & 25 & 0 & 0 & 0 & 0 & 0 & 0 & 0 & 0 & 0 & 0 \\
\hline & & 26 & 0 & 0 & 0 & 0 & 0 & 0 & 0 & 0 & 0 & 0 \\
\hline & 2 & 27 & 0 & 0 & 0 & 0 & 0 & 0 & 0 & 0 & 0 & 0 \\
\hline & 2 & 28 & 0 & 0 & 0 & 0 & 0 & 0 & 0 & 0 & 0 & 0 \\
\hline & 5 & 29 & 0 & 0 & 0 & 0 & 0 & 0 & 0 & 0 & 0 & 0 \\
\hline & 5 & 30 & 0 & 0 & 0 & 0 & 0 & 0 & 0 & 0 & 0 & 0 \\
\hline
\end{tabular}

A : Medicated with $0.025 \%$ of tylosin

B : Medicated with $0.05 \%$ of tylosin

C: Non medicated

NAKAMURA et al. reported that when pigs were subjected to single administration with 50 $\mathrm{mg} / \mathrm{kg}$ of tylosin phosphate orally, the tylosin was distributed in many tissues within 10 to 60 minutes and could not be detected 24 hours after the treatment, but some remained in digestive tissues. ${ }^{8}$ KLINE and WAITT reported that residual tylosin was detected in liver tissue from swine receiving tylosin phosphate at $1000 \mathrm{~g} /$ ton of food up to slaughter. This dosage is about $30 \mathrm{mg} / \mathrm{kg}$ as daily average. But no residues were detected in tissue when tylosin phosphate was fed at less than $500 \mathrm{~g} /$ ton.9) Daily value in the high dose of tylosin used in our experiments coincides much closely with the value reported by NAKAmura et al. Residual tylosin in marrow or duodenum after treatment is essentially similar to those of their reports. It is considered that distribution and absorption of tylosin phosphate appeared to be the same as tylosin tartrate. 


\section{IRITANI - HidAKA $\cdot$ KITABATAKE - ISE}

Undetectable tylosin after withdrawal might indicate that tylosin was not bound to the tissues of the pig, moreover, tylosin treatment was limited to cure swine dysentery for a short period of time, therefore, tylosin residue might be negligible in the tissue of pig.

\section{References}

1) McGuire, J.M., W.S. Boniece, C. E. Higgens, M. M. Hoehen, W. M. Stark, J. Westhead, and R. N. Wolfe, Antibiot Chemother 11: 320-327. 1961.

2) Curtis, R. A., Can Vet J 3: 285-288. 1962.

3) Jordan, C.E., Waitr, W.P., and T.M. Means, J Anim Scj 19: 1269. 1960.

4) Gossett, F. O., and J.A. Miy at, H A Vet Met 59: 169-171. 1964.

5) Doornenbal, H., Can J Comp Med 29: 179-182. 1965.

6) Huber, W.G., Advances in Veterinary Sci and Comparative Med 15: 101-132. 1971.

7) Yoshida, M., H. Hoshi, S. Yonezawa, H. Nakamura, and R. Yamaoka, Japan Poultry Sci 10: 23-28. 1973.

8) Nakamura, H., H. Azechi, S. Yonezawa, S. Sato, and K. Ninomia, Ann Rep Nat Vet. Assay Lab 9: 65-71. 1972.

9) KLINE, R. M., and W. P. WAITT, J Ass Offic Anal Chem 54: 112-115. 1971.

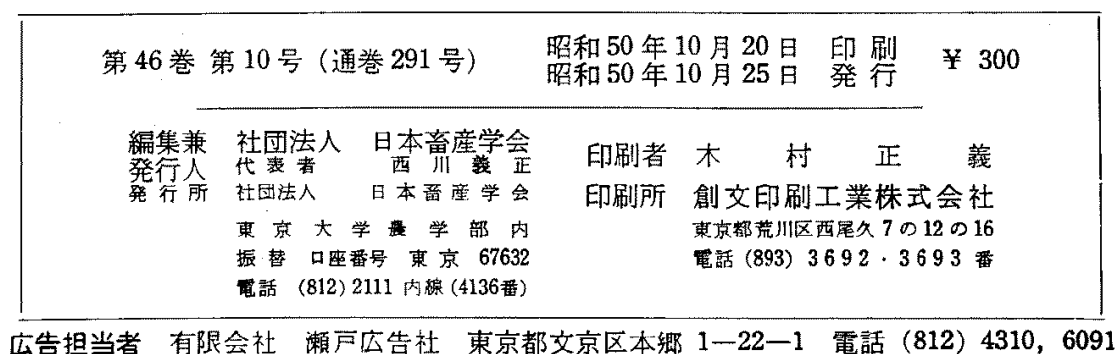

